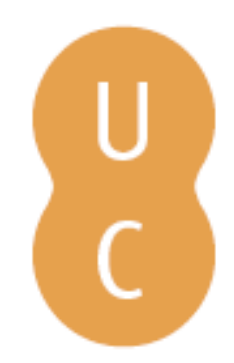

\title{
pompalina
}

\section{Horacio y el tópos de la gloria poética}
Autor(es):
Bauzá, Hugo Francisco

Publicado por: Centro de Estudos Clássicos e Humanísticos; Imprensa da Universidade

URL

persistente:

URI:http://hdl.handle.net/10316.2/32055

DOI:

DOI:http://dx.doi.org/10.14195/978-989-8281-11-1_7

Accessed : $\quad$ 26-Apr-2023 10:36:29

A navegação consulta e descarregamento dos títulos inseridos nas Bibliotecas Digitais UC Digitalis, UC Pombalina e UC Impactum, pressupõem a aceitação plena e sem reservas dos Termos e Condições de Uso destas Bibliotecas Digitais, disponíveis em https://digitalis.uc.pt/pt-pt/termos.

Conforme exposto nos referidos Termos e Condições de Uso, o descarregamento de títulos de acesso restrito requer uma licença válida de autorização devendo o utilizador aceder ao(s) documento(s) a partir de um endereço de IP da instituição detentora da supramencionada licença.

Ao utilizador é apenas permitido o descarregamento para uso pessoal, pelo que o emprego do(s) título(s) descarregado(s) para outro fim, designadamente comercial, carece de autorização do respetivo autor ou editor da obra.

Na medida em que todas as obras da UC Digitalis se encontram protegidas pelo Código do Direito de Autor e Direitos Conexos e demais legislação aplicável, toda a cópia, parcial ou total, deste documento, nos casos em que é legalmente admitida, deverá conter ou fazer-se acompanhar por este aviso.

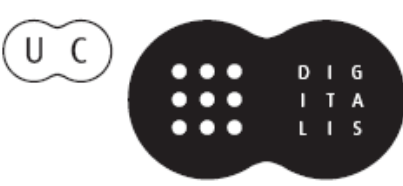




\section{Horácio \\ e a sua \\ Perenidade}

\section{Maria Helena Rocha Pereira, José Ribeiro Ferreira e Francisco de Oliveira}

IMPRENSA DA UNIVERSIDADE DE COIMBRA 


\title{
HORACIO Y EL TÓPOS DE LA GLORIA POÉTICA
}

\author{
Hugo Francisco Bauzá \\ Universidad de Buenos Aires
}

\section{Introducción}

\author{
Exegi monumentum aere perennius \\ Regalique situ pyramidum altius, \\ Quod non imber edax, non Aquilo impotens, \\ Possit diruere aut innumerabilis \\ Annorum series et fuga temporum
}

clama Horacio en una oda memorable ${ }^{1}$ en la que, al ser consciente de haber erigido "un monumento más perenne que el bronce", profetiza para su nombre una suerte de sobrevida mientras dure el mundo romano; éste políticamente se desmembró al ser invadido por los germanos, sin embargo el corpus poético de Horacio perdura incólume hasta nuestros días. Esta circunstancia explica y justifica que en este congreso alusivo al Día de la Latinidad articulemos nuestros trabajos en torno de un único tema: "Horacio y su permanencia".

El caso dellírico latino es uno de los más explícitos en cuanto a la valoración de su arte y, en consecuencia, a la noción de perennidad reservada a su poesía. Por lo demás, Horacio tiene también conciencia de ser, junto con Virgilio, uno de los principales artífices de un estado nuevo y, en consonancia con él, artífice también de la pax Romana. En ese sentido puedo decir, sin temor a equivocarme, que el mantuano y el venusino son quienes han contribuido, de manera decisiva, a afianzar los pilares ideológicos del Principado a la vez que, al exaltarlos mediante sus carmina, han logrado substraerlos de la circunstancia histórica concreta, del tiempo voraz y, por tanto, del olvido. ¿Qué serían, pues, la antigua Roma, la paz augustal o el mismo Princeps de no haber sido celebrados por los dos grandes vates del Imperio?

Lo cantado por el poeta se adscribe a un tempo intemporal, que es el tiempo del arte. Esta suerte de intemporalidad es la que confiere cierto grado de eternidad a todo lo glorificado por la poesía. Un himno de Píndaro, hoy perdido pero cuyo contenido conocemos por Arístides $^{2}$, refería que Zeus, tras vencer a los Titanes, consultó a las restantes deidades acerca de si su labor estaba completa, éstas le habrían respondido que era menester la presencia de seres que con sus cantos celebraran su gloria. Fue entonces cuando surgieron las Musas, engendradas precisamente de la unión de Zeus y Mnemosyne, para que la gesta del olímpico, subtraída del olvido merced a la memoria, se proyectara sin ocaso ya que el canto del poeta plenifica la existencia.

\footnotetext{
${ }^{1}$ Carmina III 30, 1-5.

${ }^{2}$ II 142.
} 
El carácter celebratorio confiere una suerte de sobrevida a todo lo cantado por el poeta y por esa circunstancia Horacio puede proclamar sin jactancia: non omnis moriar multaque pars mei / uitabit Libitinam (c. III 30, 6-7). Del carácter celebratorio y del aspecto intemporal de la poesía participan también otros líricos del círculo augusteo, pienso principalmente en Propercio y Ovidio. Del primero evoco un dístico revelador: Fortunata, meo si qua es celebrata libello / carmina erunt formae tot monumenta tuae (III 2, 17-18) 'Afortunada, puesto que has sido celebrada en mi poemario. / Mis poemas serán un monumento a tu memoria', donde reaparece la noción horaciana de monumentum a la que he aludido; la otra corresponde al poeta Ovidio. Éste, en uno de sus Amores (I 15, 32), declara: carmina morte carent 'los versos carecen de muerte' ya que el arte poética, a diferencia de las artes de espacio, puede escapar al desgaste que, naturalmente, determina el paso del tiempo.

Las Musas y Apolo, el dios Mousegétes, están omnipresentes en la poesía horaciana; son ellos lo que le brindan el sesgo ontológico que le proporciona un hálito de eternidad. Así lo declara el poeta principalmente en c. IV 3 donde, casi al final de su carrera ${ }^{3}$, agradece a Melpómene el haberle conferido éxito como poeta.

Algunas anécdotas vinculadas con la primera infancia de Horacio - y que él mismo se ocupó en subrayar - sugieren cierta surveillance - ¿divina? - que habría evitado que el futuro poeta pereciera víctima de serpientes y de otras alimañas, ¿̇se trata de una simple deuda con la retórica del género o el genuino reconocimiento de fuerzas que escapan al dominio de lo racional? Tales hechos, sumados a otros prodigios que le habrían acaecido (así por ejemplo la aparición de un rayo en un día sereno, lo que el poeta tuvo por un hecho extraordinario (cf. c. I 34), parecen explicar el respeto del lírico por esas fuerzas misteriosas y por el dios oracular; a éste, por ejemplo, celebró en diversas ocasiones ${ }^{4}$, con lo que a un mismo tiempo otorgaba una pátina de sacralidad tanto a su persona, cuanto a su poesía. También en sus Odas agradece a la Musa el reconocimieto de la valía de su canto ya que en vida alcanzó renombre al punto de llegar a ser señalado por el dedo del viandante como Romanae fidicen lyrae 'tañedor de la romana lira' (IV 3,23) y, pese a su reticencia respecto del vulgo como manifiesta en una composición, incluso entre el pueblo, logró fama y popularidad, tal como también le sucedió a Virgilio ${ }^{5}$.

Dignum laude uirum Musa uetat mori:/ caelo Musa beat'la Musa no permite que el varón digno de alabanza muera: / la misma Musa lo conduce al cielo' refiere el venusino en una de sus composiciones más conocidas (Carm. IV 8, 28-29) con lo que rubrica el carácter de perennidad que confiere la inspiración

${ }^{3} \mathrm{La} O d a$ es posterior al Carmen saeculare, que es del año 17 a.C.

${ }^{4} \mathrm{Cf}$,. entre otros carmina, I 34; IV 6, amén del Carmen saeculare.

${ }^{5}$ Sobre el mantuano merece evocarse que en una ocasión cuando en un teatro de Roma Cytheris, liberta de Volumnio, dramatizaba Bucólica VI el público reconoce a Virgilio escondido entre la multitud y ante ese hecho se pone de pie para rendirle homenaje, tal como lo hacía frente a Augusto; R. Brasillach recrea admirablemente ese hecho imaginando que el Poeta rougissant et stupéfait, il ne savait où se mettre. Mais cétait sa première rencontre avec la gloire (Présence de Virgile, París, Plon, 1960, p. 95). 
"musical". Esta referencia, que se advierte como un tópos de la obra horaciana, resguarda a sus carmina de la mirada intrascendente de los neófitos. Por lo demás, cuando en el inicio de una de sus Odas (III 1) manifiesta: Odi profanum uolgus et arceo 'odio y aparto al vulgo profano', tal declaración no debe ser tenida como un rechazo de carácter social, sino que lo de "vulgo profano" debe ser inteligido en el sentido de no iniciado en el misterio de las Musas o, en otro lenguaje, en el misterio de lo que eternamente es, y Horacio se arroga el privilegio - ¿o la gracia? - no sólo de estar bajo el amparo de la Musa, sino también de ser Musarum sacerdos.

Frente a la tradición platónica ${ }^{7}$ que considera al poeta un enajenado - en tanto que poseso por un entusiasmo al que no puede oponer resistencia -, el venusino, en el acto de poetizar, parece atender a una doble vertiente: por un lado el escrupuloso cuidado formal, el labor limae, la concepción de una poesía cincelada con buril a la manera de lo que en los tiempos modernos apreciamos en los parnasianos, su métier entendido como el de una abeja laboriosa; por el otro, inspirado por la Musa y, en ocasiones, por Baco (cf. c. I 18 y II 19). Con todo, su referencia a las hijas de Mnemosyne no debe ser entendida como una posesión plena sino, antes bien, como una suerte de operación alquímica de la memoria que permite apreciar el mundo del ser, el de las esencias o, en lenguaje del mismo Platón, el de la alétheia, término éste cuya etimología - sin Leteo - nos recuerda el río cuyas aguas borraban la memoria e impedían, por tanto, recordar. Así, pues, vemos que en el venusino la poesía es recuerdo y al mismo tiempo, descubrimiento. Por su vínculo con las Musas su lírica deviene música, lo que sugiere una instauración en la armonía que el poeta alcanza por obra de estas deidades.

Sin ser meramente retórico y sin caer tampoco en una devoción a ultranza, el vínculo de Horacio con las Musas se articula como un acercamiento respetuoso a un culto a la Memoria gracias al cual puede recuperar la armonía originaria y volcarla en sus composiciones. Merced a la Musa el poeta y su canto superan el aquí y el ahora y atisban el punto de inflexión en que lo temporal se enlaza con lo eterno.

La Musa le ha permitido liberarse de la turbación ciudadana, de la envidia, de las pasiones, del encarcelamiento de lo temporal; gracias a ella ha podido pasar del tiempo perdido al tiempo reencontrado ${ }^{8}$. Consciente de ese privilegio asume gozoso ser Musarum sacerdos y, como tal, en el último libro de Odas alaba a estas deidades ya que también merced a ellas tomó conciencia de lo noble y elevado de su ministerio. Su misión, en consecuencia, será la de participar a todos, a través de su poesía, esa singular experiencia de vida.

En cuanto a la tradición retórica concerniente a la Musa en la que se filia Horacio, amén de los ejemplos que proporciona la poesía helénica, hay que

\footnotetext{
${ }^{6}$ Por otra parte, en $c$. III 11 habla del carácter taumatúrgico de la música celebrado por la poesía órfica en tanto que es capaz de detener incluso los suplicios infernales.

${ }^{7} \mathrm{Fedro,} 254 \mathrm{a}$.

${ }^{8}$ Así, por ejemplo L. Deschamps titula su trabajo: "Il tempo in Orazio ossia dal tempo perduto al tempo ritrovato”, in Orpheus, n.s. IV (1983) fasc. 2, pp. 195-214.
} 
recordar los que corresponden a la latina; así el de Lucrecio quien en su poema, amparado en su amor a las Musas, confiesa su "magna esperanza de gloria".

Nec me animi fallit quam sint obscura; sed acri
Percussit thyrso laudis spes magna meum cor
Et simul incussit suauem mi in pectus amorem
Musarum, quoi nunc instinctus mente uigenti
Auia Pieridum peragro loca... (I 922-926)

No me engaño en mi ánimo cuán oscuro es el sitio en que entro; pero con agudo tirso una gran esperanza de gloria ha golpeado mi corazón y le ha infundido a la vez un dulce amor a las Musas; azuzado por él, recorro ahora, con vívida mente, los intransitados parajes de las Piérides.

La "magna esperanza de gloria" cantada por Lucrecio y que le infunde suauem (...) amorem Musarum 'un suave amor a las Musas' es también el impulso que dinamiza el poetizar horaciano.

Ese deseo de gloria alcanzada mediante la poesía registra también otros antecedentes que han servido de incitación al propio Horacio; pienso, por ejemplo, en Ennio cuando declara Volito vious per ora virum 'volaré vivo en boca de los hombres", o en Virgilio que en una de sus Geórgicas (III 9), expresa su deseo de tollere humo uictorque uirum uolitare per ora 'elevarme de la tierra y volar victorioso por boca de los hombres'.

Virgilio, Musarum sacerdos al igual que Horacio, consciente de la valía de su canto y, en consecuencia, de su perennidad, también como el venusino anuncia la erección de una obra marmórea (templum de marmore ponam, G. III 30) en homenaje a Augusto que imagina destinada a desafiar los embates del tiempo: este templum no es otra cosa que su poesía.

\section{Su gloria poética}

Sus odas nos brindan imágenes tan logradas que han trascendido el marco compositivo para el que fueron concebidas y que, por lo tanto, han adquirido vida autónoma; pienso, por ejemplo, en frases como dulce et decorum est pro patria mori (III 2, 13), odi profanum uolgus et arceo (III 1, 1) carpe diem (I 11, 8), nunc est bibendum (I 37, 1), aurea mediocritas (II 10, 5) uiuitur paruo bene (II 16,13), puluis et umbra sumus (IV 7,16$)$ o aequam memento rebus in arduis / seruare mentem (II 3,1-2) que se citan en las circunstancias más diversas, sin que muchas veces sepamos que corresponden a versos de las Odas de Horacio. Se trata de imágenes que, a la par que talladas por el buril de un artesano en el hornillo alquímico de su quehacer poético, encierran preceptos morales que valen por siempre ya que apuntan al centro de lo humano. En ese afán

\footnotetext{
${ }^{9}$ Según una tradición recogida en Vahlen (cf. Epigr. I), esta declaración formaba parte del epitafio de Ennio, donde se leería: Nemo me dacrumis decoret neque funera fletu / faxit. Cur? Volito vivus per ora virum (cit. por V. Cristóbal en la nota introductoria a la traducción de M. Fernández Galiano a las Odas y Epodos de Horacio, Madrid, Cátedra, 1990, p. 224).
} 
generalizador, advirtamos que Horacio sacrificó lo personal en aras de lo universal, por lo que su mensaje vale por siempre.

Sus cuatro libros de Odas - que merced a su sabia arquitectura constituyen una suerte de catedral lírica - sobresalen por la exigencia de una perfección formal ajena a los fuegos fatuos de la improvisación y al brillo inane de las apariencias; ellos desenmascaran la vacuidad toda vez que orientan su discurso en pro de las esencias. Sus composiciones muestran equilibrio y armonía ya que participan del concepto clásico de lo firme, vale decir, de lo que está más allá de la mudanza de los tiempos y así, muchas de sus odas - al igual que las de Píndaro - alcanzan el plano inmarcesible de la gnóme o sentencia. En ese sentido apreciamos que su poesía se presenta, en su mayor parte, indiferente a las circunstancias políticas ya que, fiel a una visión transhistórica, preconiza su adhesión a valores eternos. De ese modo su canto, a la par que se ofrece como una alocución lírica y moral a un mismo tiempo, cuando logra liberarse de lo anecdótico y del lastre de lo temporal, produce la transformación musical del mundo ${ }^{10}$ gracias a la cual devienen sublimes las cosas celebradas, aun las más pequeñas.

Entre otras cuestiones que acrecientan su gloria poética está el valor inclaudicable de los motivos que aborda: el desarrollo de una filosofía de vida expresada con impecables concisión y maestría, el aprovechar el momento fugaz no porque pase, sino porque se da pleno de riqueza (y en ese sentido Horacio nos enseña a percibir la eternidad aun en el instante), el alertarnos de que el deseo insaciable de poseer es, en definitiva, la fuente de casi todos nuestros males o el instarnos a tomar posesión de lo que se ama como una forma de vencer la muerte o, entre otros, la asunción de que le bien suprême est la maîtrise de soi ${ }^{11}$.

En cuanto a lo poético stricto sensu, son de subrayar el saber enlazar las palabras más simples de manera infrecuente con lo que logra imágenes imprevisibles, así el manejo certero a la hora de combinar un sustantivo con un adjetivo inesperado - éste suele proceder del campo de la abstracción, aquél del terreno de lo concreto - con lo que su lírica adquiere resonancias inusitadas. A diferencia de Píndaro que parte de lo universal para llegar a las cosas, Horacio recorre el camino inverso: parte de las cosas para llegar a lo universal y, de ese modo, las sublimiza.

Tras una secuencia de hechos fratricidas que quebraron la paz de Brindis, Horacio creyó que sobre Roma debía pesar una maldición - ¿acaso la culpa por el crimen de uno de los gemelos? Frente a esa aetas deuoti sanguinis el poeta, en su Epodo XVI, nos habla de la existencia de un ámbito incontaminado que Júpiter tiene reservado para los piadosos: las islas dichosas en las que, como otrora hicieron los foceos (vv. 17-18), propone refugiarse. En la lente entonces epicurea de Horacio, quizá haya que entender esas islas como una imagen o

\footnotetext{
${ }^{10}$ Ad hoc remito a M. von Albrecht, "Musik und Dichtung bei Horaz", in Atti del Convegno di Venosa, Comitato Nazionale per le celebrazioni del bimillenario della morte di Q. Orazio Flacco, Venosa, Ed. Osanna, 1993, pp. 75-100.

${ }^{11}$ P. Grimal, ibid., p. 63.
} 
símbolo $^{12}$ que alude a "una pura región que tiene asiento en el espíritu"13. Con los años el propio Horacio advierte que en lo que a él respecta ese ámbito incontaminado donde puede darse la salvación será su poesía, construida al margen de los vaivenes de la política, de la envidia ciudadana y de los recelos que a diario socavan la res publica.

\section{La poesía como celebración y fundamento del imperium}

Después de la batalla de Accio en que las fuerzas republicanas fueron vencidas el horizonte político de Roma mudó de manera sensible; no se trata ya de sobrevivir a un nuevo orden de cosas sino, antes bien, de edificar un orden nuevo. La esperanza pareció renacer y con ella el deseo de integrarse a ese mundo en gestación. Es así como Horacio y Virgilio, sin abandonar de manera definitiva sus ideas epicureas tendientes al logro de la hedoné katastematiké, se acercan a ciertos postulados estoicos, en particular a aquellos que se vinculan con la participación de las mentes lúcidas en los asuntos que atañen a Roma y, muy en especial, a los referidos a la constitución del nuevo orden que el Princeps se esforzaba por imponer. En ese cometido Horacio se siente vate y así lo proclama (Carm., I 1, 29-36 y Carmen saeculare, v. 76); corresponde referir que esa dignidad, a la vez que acentúa su misión sacerdotal, acrecienta la soledad del poeta.

Desde esa posición se erige en mentor de conciencias y serán sus versos los encargados de difundir - con sutil maestría y muchas veces de manera velada - los lineamientos de fondo en los que pretende sustentarse la política augustea: moderación, austeridad, paz. A partir de entonces la política del Princeps alienta a que retornen al Lacio Fides, Pax, Pudor, Honos y, con ellos, Virtus y Copia, y los versos de Horacio se ocupan en recordarlo.

Consciente de su rol principalísimo en la consolidación del nuevo estado Horacio orienta su poesía a fortalecer, de manera visceral, l'édification de cette mystique du régime augustéen ${ }^{14}$; es así como surgen las seis primeras odas del libro III las que -junto al Carmen saeculare - apoyan las reformas augusteas en favor de la unificación del mundo romano y de la promesse d'une pacification universelle ${ }^{15}$.

Estas seis composiciones, tanto por la identidad de su metro - la estrofa alcaica -, cuanto por su temática, constituyen una unidad que se presenta a modo de canto gnómico en pro de la moral cívica que el Princeps entendió necesaria imponer para evitar la reiteración de los vicios del pasado que dieron origen a contiendas fratricidas. Su ética ciudadana pretendía atemperar las discordias civiles, recuperar la paz y unificar el mundo romano, y para ello Augusto recurría a los poetas - Virgilio, Horacio y en menor grado, Propercio - a fin de que exaltaran y difundieran su mensaje.

${ }^{12}$ Sobre el valor del símbolo en Horacio, remito a V. Pöschl, "Simbolismo in Orazio", en Atti cit., pp. 101-109.

${ }^{13}$ K. Büchner, Historia de la literatura latina, versión española de A. Ortega Carmona, Barcelona, Labor, 1968, p. 254.

${ }^{14}$ P. Grimal, Horace, Paris, Seuil, 1958, p. 71.

${ }^{15}$ J. Perret, Horace, Paris, Hatier, 1959, p. 89. 
La primera de estas odas, en la que alientan marcadas notas epicureístas, es una invitación - acorde con el mos maiorum tradicional de los latinos - a una vida austera. No es el oro el que proporciona felicidad, sino el tener la conciencia pura: una fortuna cuantiosa no libera ni de las preocupaciones, ni de los remordimientos (Carm., III 24).

La segunda es un llamado a la nueva generación a fortalecerse espiritualmente; sólo al despreciar los bienes materiales y al rechazar el éxito lisonjero es como el hombre alcanza la uirtus: ésta es un bien supremo y una de las vías de acceso a la inmortalidad (vv. 21-22). Aborda luego al motivo del silencio y la moderación que, amén de constituir dos de sus tópoi más preciados, parecen aludir a acontecimientos infautos que le eran contemporáneos, así, por ejemplo, lo interpretan F. Plessis y P. Lejay quienes ven en ellos una referencia - aunque elíptica - a la comprometida situación por la que atravesaba el poeta Galo quien, pocos años más tarde, habría de pagar su hybris con el suicidio ${ }^{16}$.

La tercera, tras abandonar el carácter gnómico de sus primeros versos, irrumpe con un clamoroso discurso en boca de Juno profetizando la grandeza de Roma (vv. 18-68). En ese sentido la victoria de los griegos sobre los troyanos no es más que aparente ya que la misma diosa - despuesta su cólera contra Rómulo (Troica quem peperit sacerdos, v. 32) - vaticina que la Hélade caerá abatida por las huestes romanas ya que Júpiter, que garantiza la justicia y el orden, está en favor de su causa.

La cuarta composición advierte que la fortuna de los imperios y en particular del romano - que es sobre el que Horacio focaliza su lente - se asienta sobre dos pilares: la inteligencia y la fuerza, estando ésta al servicio de aquélla, ya que uis consili expers mole ruit sua 'la fuerza carente de cordura se desmorona bajo su propio peso' (v. 65). Esta imagen sugiere las funciones que en la construcción del nuevo orden están reservadas al poeta y al Princeps: Augusto, merced a Horacio - que se siente inspirado por las Musas y de las que se proclama sacerdote - tiene acceso al conocimiento de las esencias y, por tanto, a lo estatuido por los hados; de ese modo el Princeps, gracias al poeta, puede contribuir al engrandecimiento de Roma.

La quinta, también de contenido cívico, profetiza que Augusto, una vez que haya anexionado a su imperio a los britanos y a los persas y vengado la derrota de Craso, será un dios en la tierra, así como Júpiter lo es en el cielo, y en la sexta después de preguntarse, no sin temor, cómo habrán de ser los hijos de una generación fratricida, advierte que el único remedio ante posibles males es el retorno a la religión tradicional y a la observancia de las costumbres de los antepasados. De ese modo Horacio celebra las reformas que Augusto, investido a la sazón con el magisterium morum, pretendía llevar a cabo: la restauración de los antiguos templos, la depuración el Senado y la promulgación de leyes tendientes a honrar los matrimonios.

Esos carmina no sólo consolidan una gloria que con la ayuda de la Musa Horacio estima merecida (Sume superbiam / quaesitam meritis et mibi Delphica

${ }^{16}$ In Horace, Oeuvres, Paris, Hachette, 1965, pp. 118-119. Para esta conjetura, entre otros testimonios, se apoyan en Ovidio (cf. Tristia II 434: linguam nimio non tenuisse mero). 
/ lauro cinge uolens, Melpomene, comam, c. III 30), sino que sin ella el imperio augustal habría permanecido en sombras ya que la poesía no sólo corona las obras de los hombres, sino también la existencia.

Horacio es consciente de la gloria que ha alcanzado mediante la poesía y por esa circunstancia en la oda con que clausura su II libro prevé, a través de una imagen significativa, su metamorfosis en un ser híbrido - mitad hombre, mitad ave ${ }^{17}$ - que, a medida que va mudando de forma, se eleva huyendo de la tierra y de la laguna Estigia.

El arte en general y la poesía en particular son de importancia decisiva a la hora de dar forma a un nuevo orden político. El Princeps es perfectamente consciente de ese hecho y por esa causa recurre a los poetas para que plenifiquen la empresa por él acometida. Virgilio, a instancias de Mecenas y del propio Augusto, contribuyó a ese propósito con sus Geórgicas y Eneida; lo haría igualmente Horacio con sus composiciones, ya por compromiso, ya por gratitud, pero también por convicción.

Tras las muertes de Quintilio Varo, de Virgilio, de Tibulo y de Propercio, Horacio se convierte en el poeta más celebrado de Roma y es, en consecuencia, la persona indicada para componer el himno que había de entonarse en la celebración de los Juegos seculares que Augusto en el 17 a. C. se esforzó en revivir.

En este carmen el poeta impreca a Febo y a Diana para que escuchen su plegaria: si Roma es obra vuestra, favoreced a su pueblo, haciendo que los deseos de Augusto, el pacificador, se cumplan. Como Apolo nos protege y Diana oye nuestros ruegos, podemos marchar en paz ya que contamos con el beneplácito de los dioses.

Horacio participa de la alegría nacida de la pacificación augustal y, merced a un patriotismo fortalecido en la idea de dioses protectores -principalmente Apolo que en Accio había inclinado el combate en favor de Augusto -, logra escapar del ateísmo de sus primeros años, ayudado también por su progresiva inclinación a ideas estoicas.

Los dioses permitieron la existencia de Roma, y también su grandeza; la Urbe devenida imperial es una prueba de la presencia y del obrar divinos en el mundo y el venusino parece admitirlo ahora, amparado en ideas estoicas, con cierta complacencia. La alabanza a Apolo y a Diana expresada en el Carmen saeculare, amén de los compromisos políticos, conlleva en Horacio cierta sacralidad ya que, como poeta, valora a Apolo en tanto dios musagétes y, como amante de los campos, invoca a Diana cual virgen de los bosques. Esta composición significó la consagración definitiva de Horacio como poeta de los nuevos tiempos, pero a su vez contribuyó a coronar la restauración llevada a cabo por Augusto.

¿Qué recuerdo tendríamos de esos juegos que celebraban la gloria del Princeps si no contáramos con los versos del venusino? Ellos, al celebrar estos ludi, no sólo les han dado un brillo singular, sino que al evocarlos los han

\footnotetext{
${ }^{17}$ Biformis, se lee en el verso 2.
} 
substraído del tiempo voraz en tanto los adscriben a la intemporalidad que confiere la poesía.

En ese orden no puedo substraerme a la tentación de evocar lo que proclama un conocido verso del poeta Hölderlin: was bleibet aber, stiften die Dichter 'lo que permanece, sin embargo, lo fundan los poetas' ${ }^{18}$.

Con todo, nos resta un interrogante, ¿’a qué obedeció el silencio que en los últimos seis años de vida se impuso el poeta? ${ }^{19}$

${ }^{18}$ Último verso del poema "Andenken".

${ }^{19}$ Se sabe que Horacio falleció en el año 8 a. C. pocos meses después de la muerte de Mecenas. Sobre el silencio de sus últimos seis años, no corresponde sugerir conjeturas a partir precisamente de un argumento ex nibilo, empero no deja de ser significativa la interpretación de J.-Y. Maleuvre quien en diversas obras denuncia un proceder criminoso por parte de Augusto del que los poetas de su entorno se habrían percatado. Maleuvre plantea, no sin fundamento, que la muerte de Virgilio habría ocurrido con la participación del Princeps; eso explicaría, entre otros hechos, el deseo de Virgilio de que su Eneida - la obra que celebraba la gens Iulia a la que pertenecía el Princeps - fuera destruida, lo que no ocurrió precisamente por orden del mismo Augusto; en cuanto a Horacio, Maleuvre estima que el venusino, alertado del trágico desenlace de su amigo no sólo evitó, tal vez por prudencia, referirse a la muerte del mantuano -lo que sorprende ya que siempre lo había recordado como "la mitad de su alma" -, sino que en seis carmina (I 3, II 20, I 28, II 6, II 9 y IV 12) entiende esa muerte según una lectura diferente a la tradicional. Ad hoc remito a dos trabajos clave de J.-Y. Maleuvre: La mort de Virgile d'après Horace et Ovide (París, J. Touzot, 1992; 2a. ed., 1999) y Petite stéréoscopie des Odes et Épodes d'Horace (París, J. Touzot, 1995). 